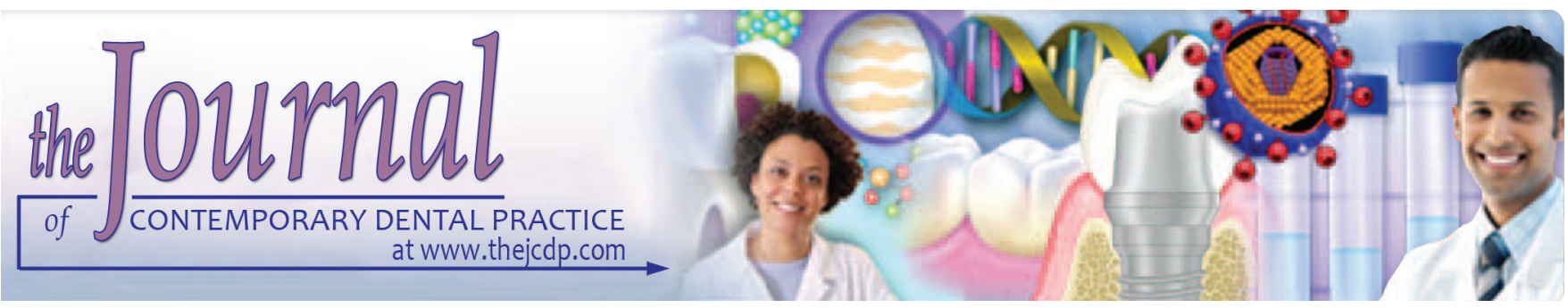

\title{
A Clinical Evaluation of Biphasic Calcium Phosphate Alloplast with and without a Flowable Bioabsorbable Guided Tissue Regeneration Barrier in the Treatment of Mandibular Molar Class II Furcation Defects
}

${ }^{1}$ Vineet Kini, ${ }^{2}$ Dilip G Nayak, ${ }^{3}$ Ashita S Uppoor

\begin{abstract}
Background: Guided tissue regeneration (GTR) therapy has shown good results in the management of mandibular molar class II furcation defects. Advances in biomaterial sciences have developed alloplastic bone replacement graft materials and bioabsorbable GTR barrier membranes with good biologic response and handling properties. The aim of this study was to compare the attachment gain and the bone fill obtained with an alloplast [biphasic calcium phosphate (BCP) $60 \%$ hydroxyapatite (HA) and $40 \%$ beta tricalcium phosphate $(\beta-T C P)]$ with and without a bioabsorbable GTR barrier [flowable poly (DL-lactide) (PLA) dissolved in N-methyl-2pyrrolidone (NMP)] in the treatment of mandibular molar class II furcation defects.
\end{abstract}

Materials and methods: A total of 20 class II furcation defects were treated in 16 patients with chronic periodontitis in a comparative study. Ten defects were treated with Camceram ${ }^{\circledR}$ (BCP $60 \% \mathrm{HA}$ and $40 \%$ - TCP) bone replacement graft material (group I) and 10 defects with a combination of Camceram ${ }^{\circledR}$ bone replacement graft material with Atrisorb ${ }^{\circledR}$ Freeflow $^{\mathrm{TM}}$, bio-absorbable GTR barrier (flowable PLA dissolved in NMP) (group II). At baseline and at 6 months postsurgery, clinical parameters of vertical probing depth (PD) and horizontal probing depth $(\mathrm{P}-\mathrm{H})$, clinical attachment level $(\mathrm{CAL})$, gingival recession (GR), and vertical depth of furcation defect (VDF) and horizontal depth of furcation defect $(\mathrm{BP}-\mathrm{H})$ were evaluated.

\footnotetext{
${ }^{1}$ Department of Periodontics, Mahatma Gandhi Mission Dental College and Hospital, Navi Mumbai, Maharashtra, India

${ }^{2,3}$ Department of Periodontics, Manipal College of Dental Sciences, Mangaluru, Karnataka, India
}

Corresponding Author: Vineet Kini, Professor, Department of Periodontics, Mahatma Gandhi Mission Dental College and Hospital, Navi Mumbai-410209, Maharashtra, India, Phone: +919769804390, Fax: 022-27433185, e-mail: drvinkin@gmail.com
Results: Statistical analysis was done with the Statistical Package for Social Sciences (SPSS) program. Intergroup comparisons made at 6 months postsurgery by unpaired Student's t-test showed mean reduction in PD in group I was $3.10 \pm 0.73 \mathrm{~mm}$ and in group II was $3.20 \pm 1.03 \mathrm{~mm}(p>0.05)$. Mean reduction in $\mathrm{P}-\mathrm{H}$ in group I was $1.60 \pm 0.69 \mathrm{~mm}$ and in group II was $1.90 \pm 0.73 \mathrm{~mm}(p>0.05)$. Gain in CAL in group I was $2.80 \pm 1.03 \mathrm{~mm}$ and in group II was $2.90 \pm 0.94 \mathrm{~mm}$ $(p>0.05)$. Change in $G R$ in group I was $-0.30 \pm 0.48 \mathrm{~mm}$ and in group II was $-0.30 \pm 0.48$ ( $p>0.05)$. Reduction in VDF in group I was $1.30 \pm 0.67 \mathrm{~mm}$ and in group II was $1.80 \pm 0.63 \mathrm{~mm}(p \leq 0.01)$. Reduction in BP-H in group I was $1.30 \pm 0.67 \mathrm{~mm}$ and in group II was $1.90 \pm 0.73 \mathrm{~mm}(\mathrm{p} \leq 0.05)$.

Conclusion: It was concluded that the combination technique of BCP alloplast with a flowable bioabsorbable GTR barrier led to better results in regard to defect bone fill as compared with when the BCP alloplast alone was used.

Keywords: Alloplast, Bioabsorbable GTR, Biphasic calcium phosphate, Bone grafting, Furcation defect, Guided tissue regeneration.

How to cite this article: Kini V, Nayak DG, Uppoor AS. A Clinical Evaluation of Biphasic Calcium Phosphate Alloplast with and without a Flowable Bioabsorbable Guided Tissue Regeneration Barrier in the Treatment of Mandibular Molar Class II Furcation Defects. J Contemp Dent Pract 2016;17(2):143-148.

Source of support: Nil

Conflict of interest: None

\section{INTRODUCTION}

New attachment formation in furcation defects treated by guided tissue regeneration (GTR) therapy has been documented. The class II mandibular furcation involvement has shown much positive response when treated by this mode of therapy. ${ }^{1}$ 
Owing to surgical trauma induced while removal of the nonresorbable membranes, ${ }^{2}$ bioabsorbable barriers were developed comprising of polylactic acid, polyglycolic acid, and their copolymers. These bioabsorbable barriers have shown successful clinical results in human trials. $^{3}$

Concurrently in mandibular molar class II furcation defects, alloplastic bone replacement graft materials have demonstrated good clinical results. Bioceramics form a category of alloplastic bone replacement graft materials, ${ }^{4}$ one of which is a two-phase calcium phosphate known as biphasic calcium phosphate (BCP). ${ }^{5}$

The aim of this study was to compare the attachment gain and the bone fill obtained with a BCP alloplast [60\% HA and $40 \%$ beta tricalcium phosphate ( $\beta$-TCP)] with and without a bioabsorbable GTR barrier [Flowable poly (DL-lactide) (PLA) dissolved in N-methyl-2-pyrrolidone (NMP)] in the treatment of mandibular molar class II furcation defects.

\section{MATERIALS AND METHODS}

\section{Materials}

Biphasic Calcium Phosphate alloplast (60\% HA and $40 \% \beta$-TCP) $\left(\right.$ CAMCERAM $^{\circledR}$; Cam-Implants BV $^{\circledR}$, the Netherlands).

Bioabsorbable GTR barrier (flowable PLA dissolved in NMP) (Atrisorb ${ }^{\circledR}$ Freeflow $^{\mathrm{TM}}$; Collagenex Pharmaceuticals, New Town, Pennsylvania, USA).

\section{Methods}

Sixteen systemically healthy patients diagnosed with chronic periodontitis were enrolled for this study. Four patients had bilateral mandibular molar class II furcation defects. These patients served as split mouth subjects, receiving $\mathrm{BCP}$ alloplast bone replacement graft material
Camceram $^{\circledR}$ composed of $60 \%$ HA and $40 \% \beta$-TCP in one defect (group I) and a combination of BCP alloplast bone replacement graft material Camceram ${ }^{\circledR}$ composed of $60 \%$ HA and $40 \%$ H-TCP with a bioabsorbable GTR barrier (flowable PLA dissolved in NMP] Atrisorb ${ }^{\circledR}$ Freeflow $^{\mathrm{TM}}$ on the contralateral side defect (group II). The remaining 12 patients, having unilateral mandibular molar class II furcation defects, were assigned to either group I (six subjects) or group II (six subjects) by coin toss. A total of 20 furcation defects were treated in 16 patients $\left[10\right.$ defects with Camceram ${ }^{\circledR}$ bone replacement graft material (group I) and 10 defects with a combination of Camceram ${ }^{\circledR}$ bone replacement graft material with Atrisorb $^{\circledR}$ Freeflow $^{\mathrm{TM}}$, bioabsorbable GTR barrier for direct application (flowable PLA dissolved in NMP) (group II)].

At baseline and at 6 months postsurgery, clinical parameters of clinical attachment level (CAL), gingival recession (GR), vertical probing depth (PD) and horizontal probing depth $(\mathrm{P}-\mathrm{H})$, vertical depth of the furcation defect (VDF) and horizontal depth of the furcation defect (BP-H) were evaluated using customized occlusal stents, UNC-15 probe, and specially calibrated Naber's periodontal probe with $1 \mathrm{~mm}$ markings (Fig. 1).

The measurements recorded from reference point on stent (RP) were as follows:

- Reference point to the cementoenamel junction (CEJ) at the furcation defect: (RP to CEJ)

- Reference point to the gingival margin (GM) at the furcation defect: (RP to GM)

- Reference point to the base of the pocket (BOP) at the furcation defect: (RP to BOP)

- Probing depth = $(\mathrm{RP}$ to BOP) minus $(\mathrm{RP}$ to $\mathrm{GM})$

- Clinical attachment level $=(\mathrm{RP}$ to $\mathrm{BOP})$ minus $(\mathrm{RP}$ to $\mathrm{CEJ}$ )

- Gingival recession $=(\mathrm{RP}$ to $\mathrm{GM})$ minus $(\mathrm{RP}$ to $\mathrm{CEJ})$. Horizontal probing depth at the furcation defect was recorded at the plane of the furcation entrance by
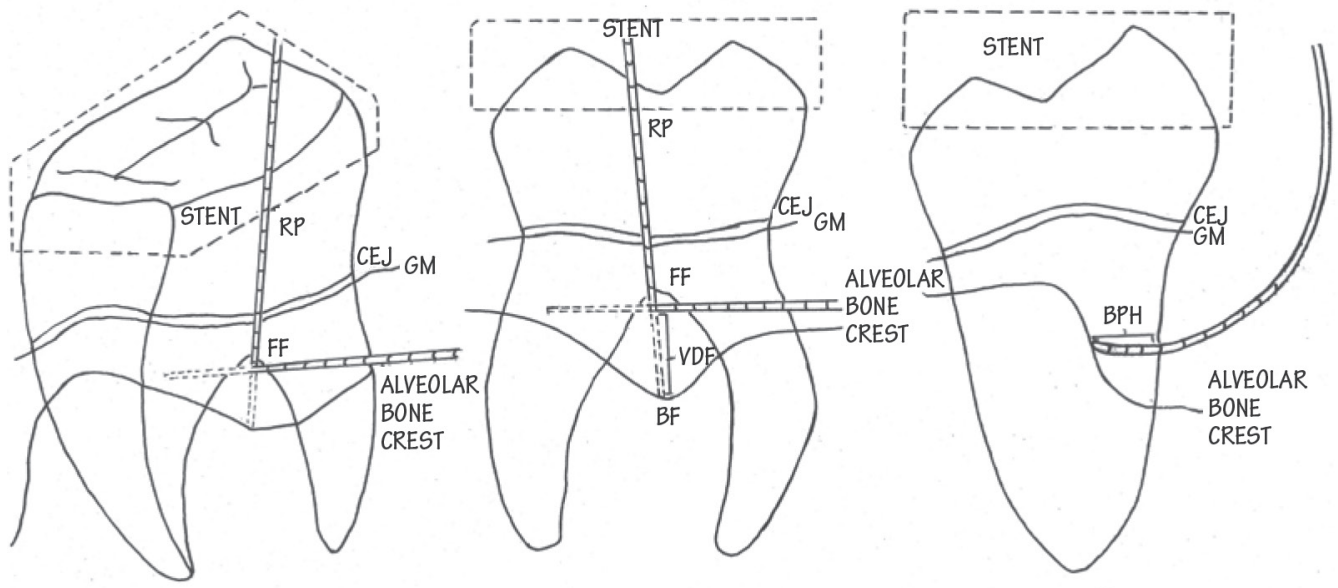

Fig. 1: Measurements taken with customized occlusal stents and periodontal probes 
a specially calibrated Naber's periodontal probe with $1 \mathrm{~mm}$ markings.

The fornix of the furcation (FF) was identified with the help of a periodontal probe and the following bone sounding measurements were recorded under local anesthesia:

- Reference point to the fornix of the furcation (RP to FF)

- Reference point to the base of the furcation defect (RP to BF)

- Vertical depth of the furcation defect $=(\mathrm{RP}$ to $\mathrm{BF})$ minus (RP to FF).

Horizontal bone sounding depth of the furcation defect was recorded at the plane of the furcation entrance by a specially calibrated Naber's periodontal probe with $1 \mathrm{~mm}$ markings.

\section{Criteria Adopted for Selecting Patients}

\section{Inclusion Criteria}

All patients were systemically healthy and were at least 18 years of age and had tendered informed consent to participate in the study. After completion of initial phase of therapy at baseline, the selected mandibular molars had the following findings:

- Furcation defects with a minimum of $3 \mathrm{~mm} \mathrm{P-H}$

- Gingival margin coronal to or at the level of the entrance of the furcation.

\section{Exclusion Criteria}

- Smokers and tobacco consumption in any form

- Pregnant patients and nursing mothers

- History of previous periodontal surgery at that site

- Third molars with furcation involvement

- Untreated nonvital teeth.

\section{Ethical Clearance}

The study was conducted in accordance with the institutional ethical committee approval and all subjects who had participated in the study had rendered informed consent to participate in the study.

\section{Surgical Technique}

Modified Widman flap surgeries were performed to gain access to the furcation defects. After thorough debridement and root instrumentation with the help of hand instruments, a decision was made as to which group the site in question was to be included through coin toss. In defects which were included in group I, Camceram ${ }^{\circledR}$ alloplast was condensed within the furcation defect to an imaginary plane connecting the root eminences (Fig. 2). For those defects that were included in group II, following placement of the alloplast, the flowable bioabsorbable GTR barrier Atrisorb ${ }^{\circledR}$ Freeflow $^{\mathrm{TM}}$ was dispensed onto the alloplast-laden furcation defect and set in place with a mist of sterile saline (Fig. 3). No stabilizing sutures for the membrane were necessary. The flaps were stabilized in their original position and primary closure was attained with the help of simple interrupted sutures with 4-0 black silk suturing material. No periodontal dressing was applied. Patients were prescribed antibiotics, analgesics, and chlorhexidine gluconate mouth rinses. Postoperative instructions were given to avoid mechanical plaque control at the surgical site for 2 weeks. Sutures were removed after 1 week. All patients were compliant, and healing was uneventful for both groups. Patients were

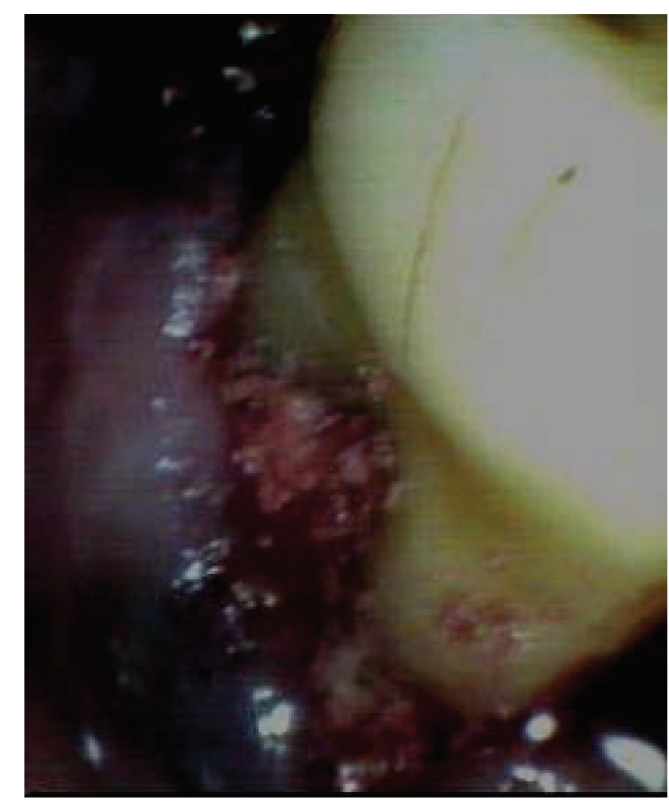

Fig. 2: Alloplast placed and condensed into the furcation defect

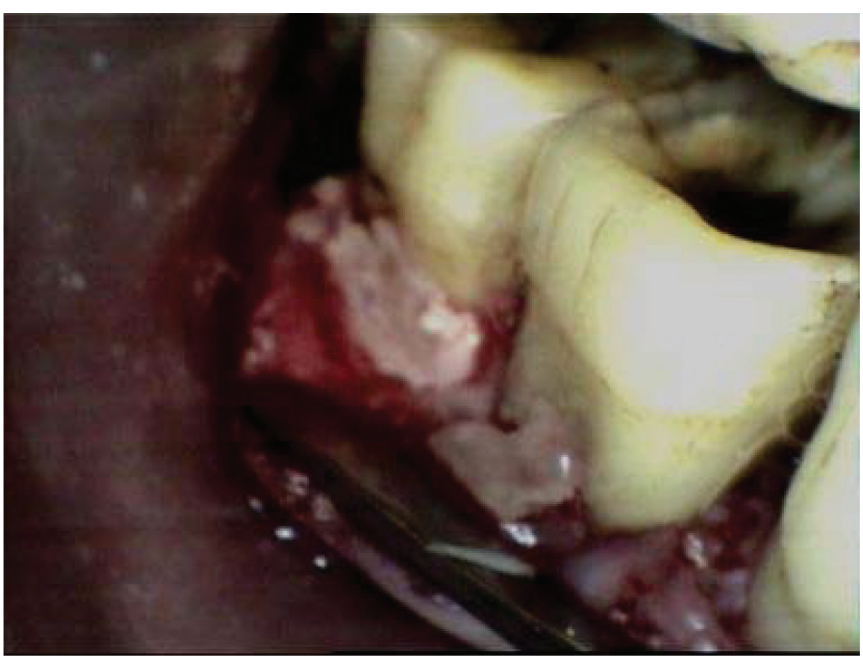

Fig. 3: Bioabsorbable barrier was applied onto the defect following the placement of the alloplast 
Table 1: Results of treatment with Camceram ${ }^{\circledR}$ bone replacement graft material (group I)

\begin{tabular}{lllll}
\hline & $\begin{array}{l}\text { Baseline mean } \\
\pm S D(\mathrm{~mm})\end{array}$ & $\begin{array}{l}6 \text { months } \\
\text { postoperatively mean } \\
\pm S D(\mathrm{~mm})\end{array}$ & $\begin{array}{l}\text { Difference mean } \\
\pm S D(\mathrm{~mm})\end{array}$ & $p$-value \\
\hline $\begin{array}{l}\text { Soft tissue measurements } \\
\text { Probing depth }\end{array}$ & $5.20 \pm 0.42$ & $2.10 \pm 0.87$ & $3.10 \pm 0.73$ & $\leq 0.001 \mathrm{HS}$ \\
Clinical attachment level & $5.70 \pm 0.67$ & $2.90 \pm 0.99$ & $2.80 \pm 1.03$ & $\leq 0.001 \mathrm{HS}$ \\
Gingival recession & $0.50 \pm 0.52$ & $0.80 \pm 0.42$ & $-0.30 \pm 0.48$ & $>0.05 \mathrm{NS}$ \\
Horizontal probing depth & $3.70 \pm 1.05$ & $2.10 \pm 0.56$ & $1.60 \pm 0.69$ & $\leq 0.001 \mathrm{HS}$ \\
Hard tissue measurements & & & & $\leq 0.001 \mathrm{HS}$ \\
Vertical depth of the furcation defect & $4.10 \pm 0.87$ & $2.80 \pm 0.91$ & $1.30 \pm 0.67$ & $\leq 0.001 \mathrm{HS}$ \\
Horizontal depth of the furcation defect & $4.70 \pm 1.05$ & $3.40 \pm 0.69$ & $1.30 \pm 0.67$ & \\
\hline
\end{tabular}

NS: Not significant; S: Significant; HS: Highly significant; SD: Standard deviation

Table 2: Results of treatment with Camceram ${ }^{\circledR}$ bone replacement graft material and Atrisorb ${ }^{\circledR}$ Freeflow ${ }^{\mathrm{TM}}$ bioabsorbable guided tissue regeneration barrier for direct application (group II)

\begin{tabular}{|c|c|c|c|c|}
\hline & $\begin{array}{l}\text { Baseline mean } \\
\pm S D(\mathrm{~mm})\end{array}$ & $\begin{array}{l}6 \text { months } \\
\text { postoperatively mean } \\
\pm S D(\mathrm{~mm})\end{array}$ & $\begin{array}{l}\text { Difference mean } \\
\pm S D(\mathrm{~mm})\end{array}$ & $p$-value \\
\hline \multicolumn{5}{|l|}{ Soft tissue measurements } \\
\hline Probing depth & $5.30 \pm 0.48$ & $2.10 \pm 0.99$ & $3.20 \pm 1.03$ & $\leq 0.001 \mathrm{HS}$ \\
\hline Clinical attachment level & $5.80 \pm 0.78$ & $2.90 \pm 1.22$ & $2.90 \pm 0.94$ & $\leq 0.001 \mathrm{HS}$ \\
\hline Gingival recession & $0.50 \pm 0.70$ & $0.80 \pm 0.78$ & $-0.30 \pm 0.48$ & $>0.05 \mathrm{NS}$ \\
\hline Horizontal probing depth & $3.70 \pm 0.82$ & $1.80 \pm 0.63$ & $1.90 \pm 0.73$ & $\leq 0.001 \mathrm{HS}$ \\
\hline \multicolumn{5}{|l|}{ Hard tissue measurements } \\
\hline Vertical depth of the furcation defect & $3.50 \pm 0.84$ & $1.70 \pm 0.67$ & $1.80 \pm 0.63$ & $\leq 0.001 \mathrm{HS}$ \\
\hline Horizontal depth of the furcation defect & $4.70 \pm 0.82$ & $2.80 \pm 0.63$ & $1.90 \pm 0.73$ & $\leq 0.001 \mathrm{HS}$ \\
\hline
\end{tabular}

NS: Not significant; S: Significant; HS: Highly significant; SD: Standard deviation

closely monitored, and clinical parameters were recorded at 6 months postoperatively.

Statistical analysis was done with the Statistical Package for Social Sciences (SPSS) program. Unilateral and bilateral sites for the alloplast with and without bioabsorbable barrier groups, i.e., groups II and I, respectively, were compared. Comparisons were made between groups I and II (intergroup) through unpaired Student's t-test and within the respective groups themselves through a paired Student's t-test (intragroup).

\section{RESULTS}

Baseline analysis did not display any significant differences between groups I and II for any of the variables assessed, suggesting that final differences between treatment groups were not influenced by initial defect characteristics, thus allowing posttreatment results to be compared (Tables 1 and 2).

When compared, the soft tissue measurements at baseline and after 6 months postsurgery within both groups I and II (intragroup) resulted in statistically significant PD reduction, $\mathrm{P}-\mathrm{H}$ reduction, and gain in the CAL ( $\mathrm{p} \leq 0.001)$. However, GR was not significant for both groups I and II (Tables 1 and 2).
Bone sounding measurements revealed significant changes in VDF and in BP-H within both groups I and II (intragroup), 6 months postsurgery $(\mathrm{p} \leq 0.001)$ (Tables 1 and 2).

At 6 months postsurgery, a statistically significant reduction in VDF was observed $(p \leq 0.001)$ within both groups I and II as compared with baseline (intragroup) (Tables 1 and 2).

Comparisons in between the outcomes of the two treatment groups (groups I and II) revealed no statistically significant difference for the evaluated soft tissue parametric measurements (intergroup). However, a statistical significance was observed in both the vertical and horizontal bone sounding parametric measurements. A statistical significance was observed $(p \leq 0.01)$ in the reduction in the VDF in favor of group II when both groups I and II were compared intergroup. Similarly, a statistical significance was observed $(\mathrm{p} \leq 0.05)$ in reduction in the BP-H in favor of group II when the two groups were compared intergroup (Table 3).

The mean percentage of the vertical and horizontal defect fill was calculated for both groups I and II (Graphs 1 and 2). 
Alloplast with and without Flowable GTR Barrier in Mandibular Molar Class II Furcation Defects

Table 3: Comparison of soft tissue and hard tissue results in groups I and II

\begin{tabular}{|c|c|c|c|c|c|c|c|c|}
\hline \multirow[b]{2}{*}{ Parameter } & \multicolumn{3}{|c|}{ Group I } & \multicolumn{3}{|c|}{ Group II } & \multicolumn{2}{|c|}{$\begin{array}{l}\text { Comparison of } \\
\text { group / vs group II }\end{array}$} \\
\hline & $\begin{array}{l}\text { Baseline } \\
\text { mean } \pm \\
S D(\mathrm{~mm})\end{array}$ & $\begin{array}{l}6 \text { months } \\
\text { postoperative } \\
\text { mean } \pm S D \\
(\mathrm{~mm})\end{array}$ & $\begin{array}{l}\text { Change } \\
\text { mean } \pm \\
S D(\mathrm{~mm})\end{array}$ & $\begin{array}{l}\text { Baseline } \\
\text { mean } \pm \\
S D(\mathrm{~mm})\end{array}$ & $\begin{array}{l}6 \text { months } \\
\text { postoperative } \\
\text { mean } \pm \\
S D(\mathrm{~mm})\end{array}$ & $\begin{array}{l}\text { Change } \\
\text { mean } \pm \\
S D(\mathrm{~mm})\end{array}$ & $\begin{array}{l}\text { Difference } \\
\text { mean } \pm \\
S D(m m)\end{array}$ & $p$-value \\
\hline Probing depth & $5.20 \pm 0.42$ & $2.10 \pm 0.87$ & $3.10 \pm 0.73$ & $5.30 \pm 0.48$ & $2.10 \pm 0.99$ & $3.20 \pm 1.03$ & $0.10 \pm 0.75$ & $>0.05 \mathrm{NS}$ \\
\hline $\begin{array}{l}\text { Clinical } \\
\text { attachment level }\end{array}$ & $5.70 \pm 0.67$ & $2.90 \pm 0.99$ & $2.80 \pm 1.03$ & $5.80 \pm 0.78$ & $2.90 \pm 1.22$ & $2.90 \pm 0.94$ & $0.10 \pm 0.91$ & $>0.05 \mathrm{NS}$ \\
\hline Gingival recession & $0.50 \pm 0.52$ & $0.80 \pm 0.42$ & $-0.30 \pm 0.48$ & $0.50 \pm 0.70$ & $0.80 \pm 0.78$ & $-0.30 \pm 0.48$ & $0.00 \pm 0.48$ & $>0.05 \mathrm{NS}$ \\
\hline $\begin{array}{l}\text { Horizontal } \\
\text { probing depth }\end{array}$ & $3.70 \pm 1.05$ & $2.10 \pm 0.56$ & $1.60 \pm 0.69$ & $3.70 \pm 0.82$ & $1.80 \pm 0.63$ & $1.90 \pm 0.73$ & $0.30 \pm 0.71$ & $>0.05 \mathrm{NS}$ \\
\hline $\begin{array}{l}\text { Vertical depth of } \\
\text { the furcation defect }\end{array}$ & $4.10 \pm 0.87$ & $2.80 \pm 0.91$ & $1.30 \pm 0.67$ & $3.50 \pm 0.84$ & $1.70 \pm 0.67$ & $1.80 \pm 0.63$ & $0.50 \pm 0.65$ & $\leq 0.01 \mathrm{HS}$ \\
\hline $\begin{array}{l}\text { Horizontal depth of } \\
\text { the furcation defect }\end{array}$ & $4.70 \pm 1.05$ & $3.40 \pm 0.69$ & $1.30 \pm 0.67$ & $4.70 \pm 0.82$ & $2.80 \pm 0.63$ & $1.90 \pm 0.73$ & $0.60 \pm 0.70$ & $\leq 0.05 \mathrm{~S}$ \\
\hline
\end{tabular}

NS: Not significant; S: Significant; HS: Highly significant; SD: Standard deviation

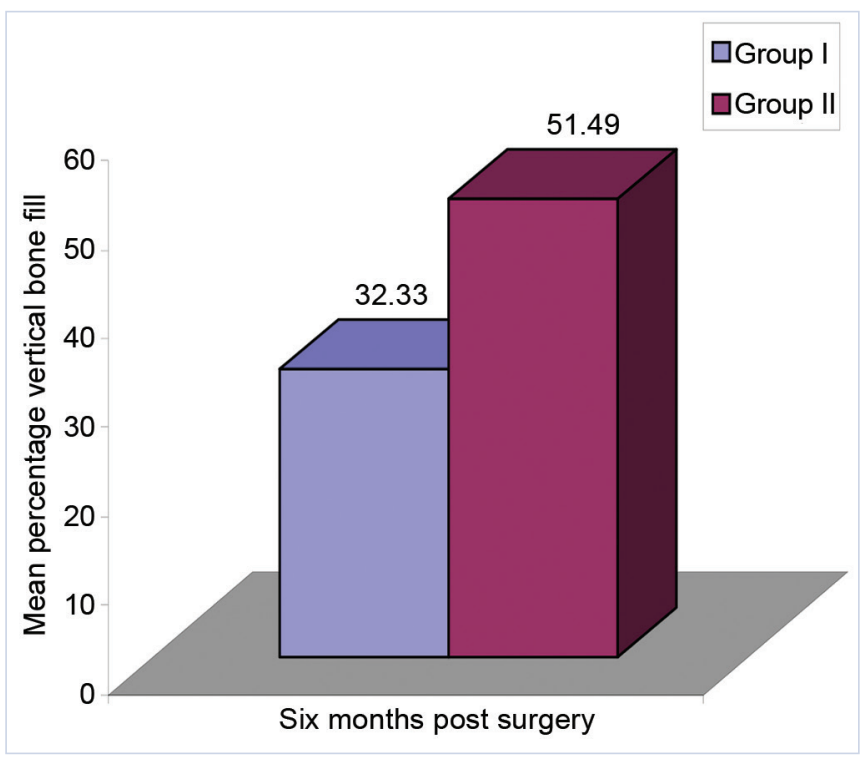

Graph 1: Mean percentage vertical bone fill for groups I and II over a period of 6 months

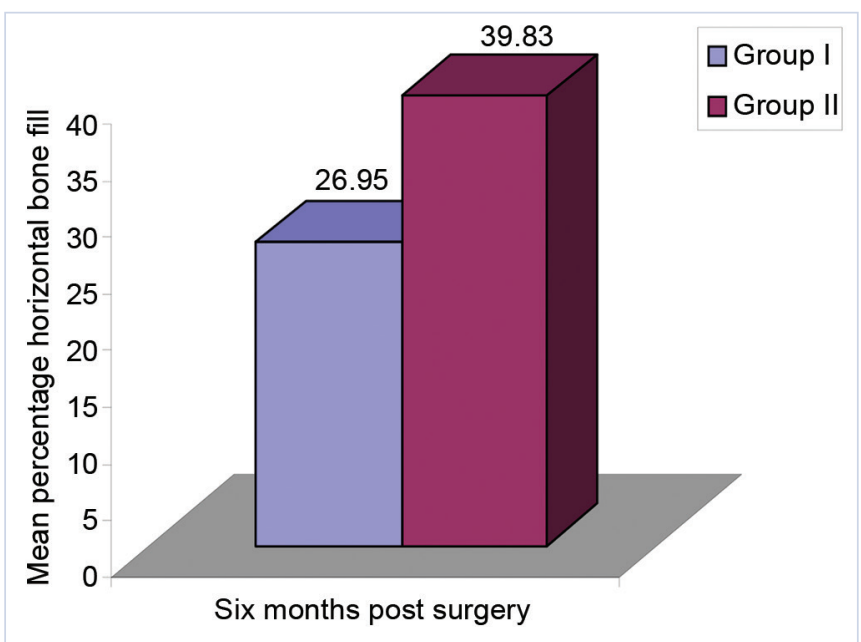

Graph 2: Mean percentage horizontal bone fill for groups I and II over a period of 6 months

\section{DISCUSSION}

In the present study, 20 furcation defects were treated with either an alloplast [BCP Camceram ${ }^{\circledR}(60 \% \mathrm{HA}$ and $40 \% \beta$-TCP)] alone, that is, group I (10 defects), or with an alloplast [BCP Camceram ${ }^{\circledR}(60 \%$ HA and $40 \% \beta$-TCP)] with a flowable bioabsorbable GTR barrier membrane Atrisorb $^{\circledR}$ Freeflow $^{\mathrm{TM}}$, that is, group II (10 defects).

Furcation defects treated with the alloplast, that is, group I, showed a statistically significant improvement in soft tissue parameters such as PD reduction, gain in CAL, and P-H reduction (Table 3).

These results are in agreement with results obtained by Nery et $\mathrm{al}^{6}$ using BCP in periodontal osseous defects and that of Jarcho ${ }^{7}$ using porous HA in human periodontal osseous defects. Shetty et $\mathrm{al}^{8}$ also voiced similar results after using a synthetic HA in the management of intraosseous periodontal defects. Similar results were found by Hemamalati et $\mathrm{al}^{9}$ who used BCP in the management of human periapical and periodontal defects with success.

Similarly, furcation defects treated with a combination of the alloplast and the bioabsorbable barrier, i.e., group II, showed statistically significant improvement in soft tissue parameters (Tables 1 and 2). These results are in tandem with the results obtained by Polson et $\mathrm{al}^{10}$ and Garrett et al, ${ }^{11}$ both using bioabsorbable barriers in treating human class II furcation defects. Similar results were also voiced by Kumar and Mehta ${ }^{12}$ using Atrisorb barriers in human periodontal osseous defects in combination with bioactive glass, and by Hou et $\mathrm{a}^{13}$ using Atrisorb barriers in human periodontal osseous defects.

Mean change in GR was recorded as equal in both groups I and II $(-0.3 \pm 0.48 \mathrm{~mm}$ respectively). This was in agreement with the results of Polson et $\mathrm{al}^{10}$ using polylactic acid-based biodegradable GTR membranes in the treatment of class II furcation defects. 
The furcation defects treated by the alloplast and the bioabsorbable barrier (group II) showed no significant change in soft tissue parameters compared with furcation defects treated with the alloplast alone (group I) (Table 3).

The hard tissue changes were evaluated using bone sounding. Bone sounding has been shown to be a reliable method in assessing the hard tissue changes as compared with surgical reentry according to the findings of Renvert et al, Mealy et al, Suh et al 2002, ${ }^{14}$ Ursell, $^{15}$ and Kim et al. ${ }^{16}$ Bone sounding has the added advantage in causing less trauma to the regenerated tissue and being more acceptable to the patient as compared with surgical reentry.

Group I showed a statistically significant improvement in hard tissue parameters such as vertical and horizontal furcation bone fill (Table 1). This is in agreement with the findings of Nery et $\mathrm{al}^{6}$ using BCP in the treatment of periodontal osseous defects.

Similarly, group II showed a statistically significant improvement in hard tissue parameters (Table 2) in agreement with the study inferences of Polson et al, ${ }^{10}$ Garrett et $\mathrm{al}^{11}{ }^{11}$ and Hou et $\mathrm{al}^{13}{ }^{13}$ all using polylactic acidbased barriers in treating human class II furcation defects.

Furcation defects treated within group II showed an average mean of $0.5 \pm 0.65 \mathrm{~mm}$ greater vertical bone fill and an average mean of $0.6 \pm 0.70 \mathrm{~mm}$ greater horizontal bone fill than the furcation defects treated within group I (Table 3 , Graphs 1 and 2), which was statistically significant.

The results are suggestive that most of the anticipated regeneration seems to have occurred in the more apical regions of the furcation defects and the more favorable results in group II may be attributed to the superior graft material confinement and the close adaptation of the fluid membrane to both the graft and the host tissues.

\section{CONCLUSION}

In view of the present findings, it may be permissible to conclude that in this study, both an alloplast and a combination technique of an alloplast with a flowable bioabsorbable GTR barrier are effective in the treatment of mandibular molar class II furcation defects. ${ }^{17,18}$

The combination technique of an alloplast with a flowable bioabsorbable GTR barrier led to better results in regard to defect bone fill as compared with when the alloplast alone was used.

\section{REFERENCES}

1. MacLain PK, Schallhorn RG. Focus on furcation defectsguided tissue regeneration combination with bone grafts. Periodontol 20002000 Feb;22:190-212.

2. Nyman S, Lindhe J, Karring T, Rylander H. New attachment following surgical treatment of human periodontal disease. J Clin Periodontol 1982 Jul;9(4):290-296.
3. Wang HL, MacNeil RL. Guided tissue regeneration: absorbable barriers. Dent Clin North Am 1998 Jul;42(3):505-522.

4. Aichelmann-Reidy ME, Yukna RA. Bone replacement grafts: the bone substitutes. Dent Clin North Am 1998 Jul;42(3):491-504.

5. Hench, LL. Ceramics, glasses and glass ceramics. Ratner, BD., Hoffmann, AS., Schoen, FJ. Lemons, JE, editors. Biomaterials science: an introduction to materials in medicine, 1st ed. California: Academic Press; 1996. p. 73-83.

6. Nery EB, Lee KK, Czajkowski S, Dooner JJ, Duggan M, Ellinger RF, Henkin JM, Hines R, Miller M, Olson JW, et al. A Veterans Administration Cooperative study of biphasic calcium phosphate ceramic in periodontal osseous defects. J Periodontol 1990 Dec;61:737-744.

7. Jarcho M. Biomaterial aspects of calcium phosphates. Properties and applications. Dent Clin North Am 1986 Jan; 30(1):25-47.

8. Shetty WS, Kohud RM, Yeltiwar RK, Vaidya SN. A new synthetic hydroxyapatite. The right answer to bone regeneration. J Indian Soc Periodontol 2002;5(1):6-11.

9. Hemamalati J, Perameswaran A, Kumar S. Bioceramics in clinical dentistry [biphasic calcium phosphate]. J Indian Dent Assoc 2001;72:228-231.

10. Polson AM, Garrett S, Stoller NH, Greenstein G, Polson AP, Harrold CQ, Laster L. Guided tissue regeneration in human furcation defects after using a biodegradable barrier. A multicenter feasibility study. J Periodontol 1995 May;66(5):377-385.

11. Garrett S, Polson AM, Stoller NH, Drisko CL, Caton JG, Harrold CQ, Bogle G, Greenwell H, Lowenguth RA, Duke SP, et al. Comparison of a bioabsorbable GTR barrier to a nonabsorbable barrier in treating human class ii furcation defects. A multicenter parallel design randomized single blind trial. J Periodontol 1997 Jul;68(7):667-675.

12. Kumar ABT, Mehta DS. Evaluation of bioactive glass (Perioglass) bone graft material and poly (DL-lactide) (Artisorb) GTR membrane in the treatment of three wall infrabony periodontal osseous defects-a clinical study. J Indian Dent Assoc 2003;74(4):207-215.

13. Hou LT, Yan JJ, Tsai AT, Lao CS, Lin SJ, Liu CM. Polymer assisted regeneration therapy with Atrisorb ${ }^{\circledR}$ barriers in human periodontal intrabony defects. J Clin Periodontol 2004 Jan;31(1):68-74.

14. Suh YI, Lundgren T, Sigurdsson T, Riggs M, Crigger M. Probing bone level measurements for determination of the depths of Class II furcation defects. J Periodontol 2002 Jun;73(6):637-642.

15. Ursell MJ. Relationships between alveolar bone levels measured at surgery, estimated by transgingival probing and clinical attachment level measurements. J Clin Periodontol 1989 Feb;16(2):81-86.

16. Kim HY, Yi SW, Choi SH, Kim CK. Bone probing measurement as a reliable evaluation of the bone level in periodontal defects. J Periodontol 2000 May;71(5):729-735.

17. Durrani F. Autogenous graft harvesting; bone potential comparison of piezosurgery, bone mill, and bone scraper. Int J Contemp Dent Med Rev 2016 Feb;2016, Article ID: 010116. doi: 10.15713/ins.ijcdmr.95

18. Hosseini SH, Kazemian M, Ghorbanzadeh S. A brief overview of cellular and molecular mechanisms of osseointegration. Int J Contemp Dent Med Rev 2015;2015, Article ID: 010415. doi: 10.15713/ins.ijcdmr.70 